\title{
Parallel pathways at the auditory periphery
}

\author{
Marcos A Cantu ${ }^{1,2}$ \\ From The Twenty Third Annual Computational Neuroscience Meeting: CNS*2014 \\ Québec City, Canada. 26-31 July 2014
}

We should consider the possibility that Low- and Highspontaneous rate (SR) auditory nerve fibers (ANFs) [1] constitute two different parallel pathways at the auditory periphery. The present study used a computational model of the auditory periphery [2] to demonstrate that Lowand High- SR ANFs have contrasting response properties. Anatomical studies suggest that Low- and High- SR ANF types have separate innervation sites (Figure 1A) on the same inner hair cell; lower-SR fibers synapse on the modiolar side and high-SR fibers synapse on the pillar side [3]. My hypothesis, prior to modeling the tuning curves (Figure 1B), was that Low Spontaneous Rate (Low-SR) fibers have a higher threshold for simulation and thus will have demonstrably sharper frequency selectivity than High-SR fibers. The results of the simulation support this framework; Low-SR ANFs were shown to have sharper frequency tuning (Figure 1B) than High-SR ANFs throughout a range of characteristic frequencies $(\mathrm{CFs})$. While Low-SR ANFs have sharper frequency selectivity (Figure 1B), High-SR ANFs have finer temporal resolution, as the rate of change of the mean firing rate in High-SR ANFs was well above that of Low-SR fibers in the simulation (Figure 1C). It would seem that Low-SR and Medium-SR fibers (i.e. Lower-SR fibers) are optimized for "place theory" frequency coding and High-SR fibers are optimized for "volley-theory" synchronous phase locking. Future modeling efforts might maintain the integrity of these two parallel pathways, optimized for fine spectral (Lower-SR) and fine temporal (High-SR) resolution, by separating rather than summing their respective outputs.
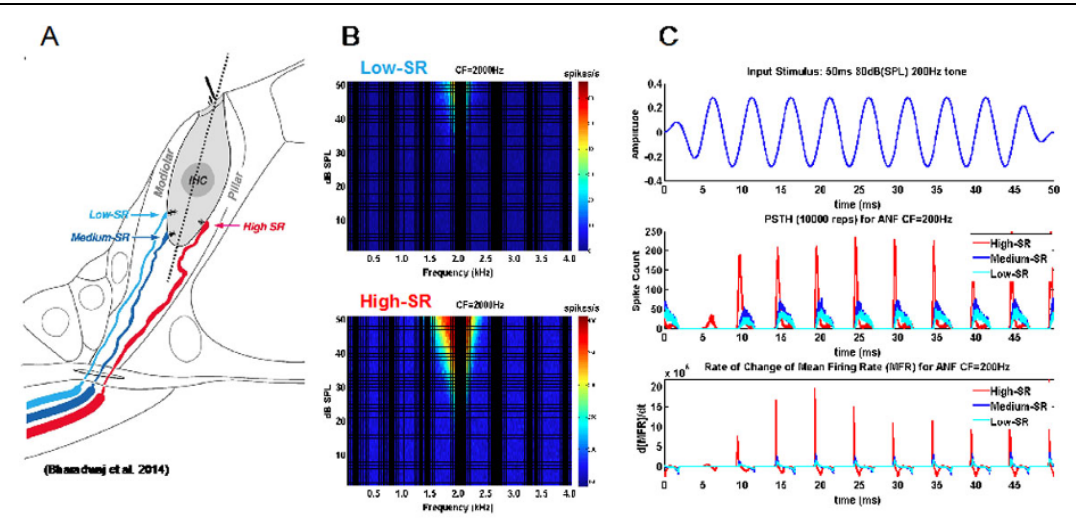

Figure 1 Innervation sites (A), tuning curves (B) and temporal response properties for Low- and High- SR ANFs

\footnotetext{
Correspondence: cantu@bu.edu

${ }^{1}$ Center for Computational Neuroscience and Neural Technology (CompNet),

Boston University, Boston, MA, USA

Full list of author information is available at the end of the article
}

(c) 2014 Cantu; licensee BioMed Central Ltd. This is an Open Access article distributed under the terms of the Creative Commons Attribution License (http://creativecommons.org/licenses/by/4.0), which permits unrestricted use, distribution, and reproduction in any medium, provided the original work is properly cited. The Creative Commons Public Domain Dedication waiver (http:// creativecommons.org/publicdomain/zero/1.0/) applies to the data made available in this article, unless otherwise stated. 


\section{Authors' details}

${ }^{1}$ Center for Computational Neuroscience and Neural Technology (CompNet), Boston University, Boston, MA, USA. ${ }^{2}$ Graduate Program for Neuroscience (GPN), Boston University, Boston, MA, USA.

Published: 21 July 2014

\section{References}

1. Liberman MC: Auditory-nerve response from cats raised in a low-noise chamber. J Acoust Soc Am 1978, 63(2):442-455.

2. Zilany MSA, Bruce IC, Carney LH: Updated parameters and expanded simulation options for a model of the auditory periphery. J Acoust Soc Am 2014, 135:283-286.

3. Bharadwaj HM, Verhulst S, Shaheen L, Liberman M, Shinn-Cunningham BG: Cochlear neuropathy and the coding of supra-threshold sound. Front Syst Neurosci 2014, 8(26).

doi:10.1186/1471-2202-15-S1-P193

Cite this article as: Cantu: Parallel pathways at the auditory periphery. BMC Neuroscience 2014 15(Suppl 1):P193.

Submit your next manuscript to BioMed Central and take full advantage of:

- Convenient online submission

- Thorough peer review

- No space constraints or color figure charges

- Immediate publication on acceptance

- Inclusion in PubMed, CAS, Scopus and Google Scholar

- Research which is freely available for redistribution

Submit your manuscript at www.biomedcentral.com/submit
C Biomed Central 